Faculty Scholarship

2004

\title{
Toward an Indigenous Jurisprudence of Rape
}

Sarah Deer

Mitchell Hamline School of Law, sarah.deer@mitchellhamline.edu

Publication Information

14 Kansas Journal of Law and Public Policy 121 (2004)

\section{Repository Citation}

Deer, Sarah, "Toward an Indigenous Jurisprudence of Rape" (2004). Faculty Scholarship. Paper 79.

http://open.mitchellhamline.edu/facsch/79 


\title{
Toward an Indigenous Jurisprudence of Rape
}

\begin{abstract}
This article sets forth some preliminary issues and perspectives for the development of indigenous models of rape jurisprudence. Part I examines the reasons for and importance of developing an indigenous jurisprudence of rape. Part II addresses tribal jurisdiction issues, particularly the current limitations on tribal authority. Part III provides a historical context for the issue, including examples of the role of colonization in the responses to sexual violence. Part IV shares some visions for the development of a contemporary jurisprudence of rape for indigenous nations.
\end{abstract}

\section{Keywords}

native women, violent crimes, criminal law, tribal law, traditions, Indian country

\section{Disciplines}

Indian and Aboriginal Law 


\title{
Toward an Indigenous Jurisprudence of Rape
}

\author{
Sarah Deer* \\ "But to speak, at whatever the cost, is to become empowered \\ rather than victimized by destruction. In our tribal cultures \\ the power of language to heal, to regenerate, and to create \\ is understood."
}

Joy Harjo, Muscogee

This article is inspired by the conversations about sexual violence I have had with Native women over the past few years. It is also informed by discussions with tribal police, prosecutors, and other criminal justice professionals who see the impact of crime in Indian country on a daily basis. I have yet to meet anyone who has lived or worked in Indian country for any length of time who does not view sexual violence as one of the most devastating threats to contemporary indigenous culture. Despite this view, very little has been written about the legal response to the sexual assault of Native women. ${ }^{2}$ This article is an attempt to articulate some potential foundations for the development of an indigenous jurisprudence of rape. While this article focuses on the legal framework for addressing sexual assault from a tribal government perspective, it will also serve to broaden the general discussions about sexual violence to include more legal analysis of colonization and cultural domination.

The justification for developing an indigenous jurisprudence of rape $\mathrm{e}^{3}$ emerges in three distinct areas: (1) the high rate of sexual violence against Native women; (2) the inability of current legal systems to adequately address sexual assault of Native women; and (3) the strong anti-rape sentiment in the traditions and belief systems of Native people. The justification is also predicated on the unique nature of sexual assault as a criminal act that has a profound impact upon human dignity and wellbeing. ${ }^{4}$

Current legal scholarship (both feminist and indigenous) does not adequately address the issue of sexual violence against Native women. ${ }^{5}$ In many ways, the sexual assault of Native women has been invisible in legal, social, and historical discourse. Native women are never even mentioned in many contemporary studies on the intersection of race or ethnicity and sexual assault. In addition, much of the legal scholarship on communities of color and sexual violence has focused on the rape of African women, including the historical use of sexual violence to facilitate the enslavement of African peoples. ${ }^{6}$ Although feminist scholarship has provided critical theories for the analysis of rape law ${ }^{7}$, it has not sufficiently addressed the experiences 


\section{Deer}

of Native women. ${ }^{8}$ On the other hand, indigenous legal scholarship often fails to address gendered violence in a substantive way. ${ }^{9}$ Legal discussions regarding the injustices and inequalities suffered by indigenous people rarely mention sexual violence. Articles and reports, which detail the atrocities against Native people focus on slavery, ethnocide, land theft, forced removal, and genocide. They fail to include any analysis of the role of sexual violence, forced childbirth, or other gendered crimes.

Today, the legal response to the rape of Native women in Indian country is largely the task of the federal and state justice systems. However, neither system is particularly effective at alleviating Indian country crime. ${ }^{10}$ Even if the non-tribal legal systems were radically improved, the federal and state systems are fundamentally inadequate to wholly address sexual violence as experienced by indigenous women. Native women need community awareness and accountability for sexual violence at the local level, preferably framed in a culturally-relevant way. ${ }^{11}$ However, legal scholarship has not kept up with the needs of community and indigenous anti-violence advocates and activists who are working daily to address the crisis in their local communities.

The role of tribal leaders and tribal justice systems in responding to rape is central to resolving the issue. To adequately address community needs, an indigenous response to rape should reflect the historical context of sexual violence as well as the contemporary realities of tribal court systems and rates of violence. A review of historical, anthropological, and sociological records may provide some foundations for beginning the important discussion regarding why and how contemporary indigenous nations should respond to sexual violence.

This article sets forth some preliminary issues and perspectives for the development of indigenous models of rape jurisprudence. Part I examines the reasons for and importance of developing an indigenous jurisprudence of rape. Part II addresses tribal jurisdiction issues, particularly the current limitations on tribal authority. Part III provides a historical context for the issue, including examples of the role of colonization in the responses to sexual violence. Part IV shares some visions for the development of a contemporary jurisprudence of rape for indigenous nations.

\section{JUSTIFICATION FOR DEVELOPING AN INDIGENOUS JURISPRUDENCE OF RAPE}

Sexual violence is only one of a multitude of social and legal issues faced by tribal governments today. Nonetheless, it is critical that tribal governments make sexual violence a priority issue. The high rate of sexual violence against Native women itself provides sufficient justification for the development of tribal jurisprudence. Moreover, sexual violence is not like every other crime - there are unique factors and impacts that warrant a separate and independent analysis. ${ }^{12}$ Specifically, Christine Boyle writes that rape, unlike other assaults, "is an assault on human dignity."13 


\section{Indigenous Jurisprudence of Rape}

\section{A. The High Rate of Sexual Assault Against Native Women}

It is difficult to obtain accurate and thorough data about the extent of sexual violence in indigenous communities. ${ }^{14}$ Native women are rarely included as target populations in research about sexual violence, and many Native women choose not to disclose violent crimes to outsiders. However, a few statistical reports on the rape of adult Native women are available, and the numbers are staggering.

Over the past five years, several national surveys ${ }^{15}$, including the National Crime Victimization Survey and the National Violence Against Women Survey, have consistently indicated that American Indian and Alaska Native women experience rates of violence far exceeding those of other racial groups. ${ }^{16}$ The National Violence Against Women Survey, for example, concluded that $34.1 \%$ of American Indian and Alaska Native women will be raped during their lifetime. ${ }^{17}$ The National Crime Victimization Survey indicates that American Indian and Alaska Native women suffer a rate of sexual assault of 7 per 1000 people, compared to 2 per 1000 for all women. ${ }^{18}$ Several other state and local studies reveal similar high sexual victimization rates among Native women. ${ }^{19}$ Individual tribal nations have also reported a high rate of sexual assault. In 2003, for example, the Navajo Nation estimated that sex crimes may account for more than 70 percent of criminal investigators' time. ${ }^{20}$

Although the reasons for these high rates are unclear, it is evident that Native women are particularly vulnerable to sexual violence. Further research is necessary to identify the unique trends and experiences of Native survivors of sexual assault. Significantly, research shows a similar high rate of sexual assault in indigenous populations around the world, which lends credence to the theory that there may be a strong correlation between colonization and sexual violence. ${ }^{21}$

\section{B. The Impact of Sexual Assault}

The impact of sexual violence on the lives of women has been well documented in mainstream academic and medical communities. Statistics themselves do not convey the incredible amount of pain and trauma experienced by survivors of sexual violence. Most survivors of rape indicate that it is more than just a physical attack. ${ }^{22}$ Rape is laden with psychological and spiritual ramifications. Claudia Card writes, "[i]t breaks the spirit, humiliates, tames, produces a docile, deferential, obedient soul.",23 Rape impacts individual women physically, emotionally, and spiritually, and creates numerous problems in the lives of the victims. ${ }^{24}$ However, insufficient research has left us with little information of specific manifestations of rape in tribal communities. One report suggests that Native women respond to childhood sexual trauma in unique ways; the same may be found for adult sexual assault. ${ }^{25}$ 
Native women who have been sexually assaulted report higher rates of depression, alcoholism, drug abuse, and suicidal ideation than those who have not experienced sexual assault. ${ }^{26}$ Substance abuse and addiction are other extremely common responses to sexual assault. One study in Alaska found that $84 \%$ of Alaska Native women entering a residential substance abuse treatment facility had experienced rape. $^{27}$ More recently, sexual trauma has been correlated with drug use and HIV sexual risk behaviors in Native women. ${ }^{28}$

In short, rape impacts more than the individual victims; it impacts the entire community. Women play significant roles in tribal communities, culturally, spiritually, and politically, and have been referred to as the "backbone" of tribal sovereignty. ${ }^{29}$ The fact that over one third of Native women have been traumatized by sexual assault inhibits their ability to contribute productively to the community. The insidious and cyclical nature of sexual violence compounds the trauma, particularly in communities where there has been no effective intervention.

Consistent and continuous reports of sexual violence in tribal communities can be described as a crisis situation. A strong response to the high rate of sexual violence experienced by indigenous women is crucial to the future safety of Native women. It has even been suggested that other social problems cannot be resolved unless psychological trauma is addressed in a systemic way. ${ }^{30}$ Because sexual violence played such a significant role in past attempts to destroy indigenous nations, it is critical that tribal nations develop and strengthen their responses to rape as a facet of sovereignty.

\section{Rape as Defined by the Colonizers}

The origins of sexual assault law in the Anglo-American system have been linked to the development of contemporary property law. ${ }^{31}$ The traditional AngloAmerican legal paradigm of rape (a stranger attacking a virgin) did not address the experience of most women.

Historically, [Anglo-American] rape law raised unique procedural hurdles for rape victims that victims of other crimes did not have to surmount. Derived from English common law and applicable in most jurisdictions until the mid to late 1970 s, these formal rules embodied clear presumptions against women who complained of having been raped. These rules included absolute exemptions from criminal liability for those men who raped their wives. They included requirements that the victim establish that she resisted her attacker to the utmost, freshly complained of having been raped and 


\section{Indigenous Jurisprudence of Rape}

corroborated her testimony with other evidence. They included biased suppositions about victims who had previously engaged in sexual intercourse outside of marriage. Finally, they included special cautionary instructions read to the jury to warn them of the fallibility of the testimony of those who complain of having been raped. ${ }^{32}$

The fact that the classical discussions about rape law focused on white women presents additional hurdles for women of color. ${ }^{33}$ Some early state laws only criminalized sexual assault when the victim was a "white woman" and left indigenous women and other women of color with no recourse. The colonialist mindset could not conceive of a legal wrong in raping a Native woman. Native women were devalued and debased, and their abuse was seen as being outside the law. ${ }^{34}$ In a 1909 Congressional debate over punishments for perpetrators of sexual assault against Native women, U.S. Representative Norris indicated, ". . . the morals of Indian women are not always as high as those of a white woman and consequently the punishment should be lighter against her." ${ }^{35}$ As recently as 1968, the Ninth Circuit Court of Appeals upheld a law that imposed a harsher penalty for the rape of a non-Indian woman than an Indian woman $^{36}$ presumably because Congress viewed Native women as immoral and therefore unworthy of protection. ${ }^{37}$ Smith notes that this legal approach is justified in the "colonial imagination" because "[t] he rape of bodies that are considered inherently impure or dirty simply does not count.",38

Even today, Anglo-American rape law fails to provide adequate intervention and adjudication for most survivors of sexual assault, including white women. Statistics indicate that sexual violence continues to be grossly underreported to law enforcement. ${ }^{39}$ A small percentage of reported rapes will result in arrest, ${ }^{40}$ and less than $1.9 \%$ will be incarcerated. ${ }^{41}$ Sexual assault cases are more than $50 \%$ likely to be dismissed as opposed to a murder case. ${ }^{42}$ Though feminists have been successful at developing and implementing major reforms of rape law since the early 1970s, it is not clear that these efforts have necessarily improved the climate for survivors of sexual assault. $^{43}$

\section{Federal and State Response to Sexual Assault in Indian Country}

There are a number of reasons not to rely on the federal and state governments as the sole adjudicatory authority over sexual violence. It is questionable whether either the federal or the state legal systems are effective at responding to or controlling violent crime in Indian country. In recent years, the lack of proactive response to rape by the federal government has been the subject of concern for Native women and tribal 


\section{Deer}

governments. ${ }^{44}$ Problems and weaknesses have been identified in both the investigation and prosecution of sexual assault, although specific evidence is difficult to obtain. Because federal prosecutorial statistics do not easily distinguish between cases of child sexual abuse and the rape of adult women, it is difficult to gauge the effectiveness of the federal response. The reports tend to show that many federal sexual abuse convictions involve child victims. ${ }^{45}$

As Dian Million writes, "Because U.S. law "polices," but does not protect, Native communities, U.S. legal jurisdiction actually contributes to the social violence and ill health that plagues many reservations and urban Indian communities." 46 Even if the federal system prosecutes a sexual assault, the adjudication often occurs in a distant place, outside the construct and control of the local community. Moreover, some federal employees who would be in a position to respond to the rape of Native women have themselves been offenders. ${ }^{47}$

Investigation of rape in Indian country presents challenges for both federal law enforcement and health care professionals, due to fractionated, antiquated, or nonexistent laws and policies. Contemporary sexual assault prosecutions are often dependent on adequate physical evidence, which is best collected by health care professionals. ${ }^{48}$ Indian Health Service, which has traditionally been funded at levels far below that needed to be effective, fails to meet the needs of Native people. ${ }^{49}$ Forensic exams, sometimes viewed as being extraneous to core health care needs, have not been a priority. Specialized training is necessary in order to gather evidence and document injuries associated with sexual assault, but the Indian Health Service does not have a standardized protocol for the collection of evidence in cases of adult sexual assault. ${ }^{50}$ Additionally, until recently, there was no funding to train IHS employees on sexual assault forensic examinations.

The lack of prosecution in state systems results in equal levels of frustration for tribal governments impacted by Public Law 280 (PL280). Tribal governments in PL280 states experience an inadequate response to violent crime, generally. ${ }^{51}$ In some PL280 states, a history of tension and hostility between tribal communities and state officials have resulted in jurisdictional "vacuums" in which violent crime, including sexual assault, persists without response. ${ }^{52}$ Problems exist in urban areas, as well. "While 10.6 percent of the Anchorage [Alaska] population is Native, 44.1 percent of sexual assault victims in 2000 and 2001 were Native.",53

However, a more foundational reason for critiquing the status quo response to rape in Indian country exists. External governments, such as the state and federal government, cannot address the unique spiritual and emotional issues that arise in the context of a sexual assault. A woman's ability to seek justice in her own community may facilitate healing and emotional wellness. This is why it is important to develop an independent legal approach. It is clear that Native women have particular vulnerability to sexual violence in contemporary society, and that this vulnerability has 


\section{Indigenous Jurisprudence of Rape}

a significant negative impact on women's lives and Native communities. Peggy Reeves Sanday, an anthropologist who specializes in the study of rape, notes that "as long as men are not accountable for their actions, women will be sexually abused." 54 Therefore, the lack of an effective response is actually feeding into the cycle of repeat offenders and victims. Tribal leaders and advocates have expressed concern over the non-response to violence in their communities, but many have not have developed their own independent strategy for responding to rape. The first step in reclaiming this power and authority will include an analysis of tribal jurisdiction over the crime itself.

\section{JURisdiction OVER Crimes of SeXUAL ViolenCE}

Tribal criminal jurisdiction has been significantly curtailed over the last 120 years. Because of a confusing maze of laws governing criminal jurisdiction in Indian Country, many people incorrectly believe that tribal governments have lost jurisdiction over felony-level crimes, including most sex crimes. While federal Indian law has placed major limitations on the ability of tribal nations to respond to violent crimes such as sexual assault, it is not impossible. An important first step in reclaiming and redefining indigenous nations' authority over rape cases requires an examination of the jurisdiction questions. Even under conservative interpretations of the case law, tribal nations retain concurrent criminal jurisdiction over sexual assault committed by Native people.

\section{A. Contemporary Tribal Jurisdiction}

Those who maintain that tribal governments do not have criminal jurisdiction over rape often refer to the Major Crimes Act ("MCA"), one of the earliest federal laws governing crimes committed in Indian country. ${ }_{56}^{5}$ While the Act authorized federal prosecution for particular enumerated crimes, ${ }^{56}$ it did not explicitly divest tribal governments of concurrent jurisdiction. ${ }^{57}$ Therefore, tribal governments maintain concurrent jurisdiction over the crimes enumerated in the MCA, including rape. ${ }^{58}$ Tribal nations affected by PL280 59 also retain concurrent jurisdiction over crimes, albeit with the state government. ${ }^{60}$ Like the MCA, PL280 does not contain an explicit divestment of jurisdiction (though it did have practical impacts on the development of contemporary tribal criminal justice systems). ${ }^{61}$ Moreover, concurrent tribal and state or federal prosecution does not violate the double jeopardy clause of the U.S. Constitution, because tribal nations are considered to be separate sovereigns. ${ }^{62}$

The Indian Civil Rights Act (ICRA) of $1968^{63}$ has imposed additional limits on tribal governments, and is often cited as another reason why tribal governments cannot prosecute crimes classified as felonies by the Anglo-American system. ${ }^{64}$ ICRA prohibits tribal courts from imposing a sentence of more than one-year imprisonment 


\section{Deer}

and/or a $\$ 5,000$ fine for any one offense. This law is often interpreted to mean that tribal courts only have "misdemeanor" jurisdiction, and therefore cannot prosecute felony-level crimes such as murder and rape. However, the ICRA sentencing limitation does not actually prohibit tribal nations from prosecuting any particular type of crime; it only controls the sanctions that can be imposed. ${ }^{65}$ It is true that tribal nations cannot respond to sex offenses in the same way as the state and federal systems. But while a one-year imprisonment and/or a $\$ 5000$ fine may not be sufficient for the crime of rape, ${ }^{66}$ the limitations in and of themselves do not actually eliminate a tribe's ability to prosecute. Moreover, ICRA does not limit other forms of criminal sanctions, such as restitution, probation, and banishment. ${ }^{67}$

The question of personal jurisdiction over defendants in sexual assault cases presents more explicit limitations. The Supreme Court decision in Oliphant $v$. Suquamish Indian Tribe ${ }^{68}$ arguably has placed tribal communities at the mercy of nonIndian criminals. In no uncertain terms, the Supreme Court ruled that tribal nations have no criminal jurisdiction over non-Indians. The opinion itself continues to be the subject of rigorous critique. ${ }^{69}$ The jurisdictional scheme sets up a system in which non-Natives who commit crimes against Natives can go unpunished. ${ }^{70}$ Significantly, recent statistics released by the U.S. Department of Justice have indicated that most Native rape victims report their assailant to be non-Native. ${ }^{71}$ If this is indeed the case, then tribal criminal justice systems cannot adequately address rape, and alternate provisions (such as civil remedies) will need to be developed. Clearly, the federal legal system has placed enormous restraints on the ability of tribal governments to adequately respond to rape.

\section{B. Contemporary Tribal Response to Sexual Assault}

Today, many tribal codes do include criminal laws on rape and sexual assault. ${ }^{72}$ A review of tribal appellate court opinions reveals that while prosecutions in tribal courts for sexual assault are very rare, they do occur. ${ }^{73}$ The Navajo Nation Department of Public Safety reported that their officers investigated 99 cases of rape in 2002, resulting in charges in 58 cases. ${ }^{74}$ However, current tribal rape laws, like many tribal laws, are modeled after Anglo-American statutes. ${ }^{75}$ Moreover, very few of the rape law reforms at the state level throughout the 1970s and 1980s have been incorporated into the tribal rape laws. ${ }^{76}$ Few, if any, current tribal laws on sexual violence incorporate a unique and independent indigenous perspective. For example, many tribes still retain a "marital" rape exemption, which essentially legalizes the rape of one's spouse. ${ }^{77}$ Many tribal rape laws require that the victim be overcome by force and/or violence, rather than basing the crime on the consent of the victim. ${ }^{78}$ One of the reasons that these laws may not have been updated is because very few tribal nations 


\section{Indigenous Jurisprudence of Rape}

actively prosecute sexual assault cases.

In addition to the prosecution of rape, some tribal governments have adopted sex offender registration laws, which require that persons convicted of sex crimes register with the tribal government. ${ }^{79}$ Several tribal nations have also passed sex offender notification laws (also known as "Megan's laws")

\section{The Relationship between Colonization and SeXual Violence}

The complete story of the disparate treatment of Native rape victims must begin with colonization. Specifically, the use of rape and sexual assault as a weapon against indigenous peoples is deeply imbedded in the history of imperialism and domination. Understanding rape as a continuation of the colonization process will provide a more contextualized analysis of rape in the lives of contemporary Native women and indigenous nations. ${ }^{81}$

Rape has been described as a "possession, a theft of both body and soul." Because of the sense of possession and displacement, the psychological impact of sexual violence can parallel the psychological impact of colonization. Thus, developing a contemporary tribal response to sexual assault can be essential to the process of decolonization. In this section, I will highlight these parallels, beginning with a look at the history of rape in tribal cultures.

\section{A. Pre-Colonization Sexual Violence}

Several scholars have suggested that sexual violence may have been extremely rare in indigenous communities in pre-Colonial times. Evidence lies in both the experience of Native women prior to contact as well as the behavior of Native men, as recorded by European explorers, settlers, and traders. For example, many writers have noted that North American indigenous cultures held women in higher regard than did European cultures. Anthropologist Peggy Reeves Sanday has postulated that in rapefree societies, women are respected and influential members of the community. ${ }^{83}$ In tribal communities, women and children were not considered to be property of men. ${ }^{84}$ Indeed, women were powerful spiritual and political leaders in many communities. ${ }^{85}$ Other evidence for low rates of sexual violence comes from historians' examinations of the behavior of indigenous men. Most commonly reported is the interesting fact that Native men did not sexually violate prisoners of war. ${ }^{86}$ Laurel Thatcher Ulrich indicates that the Puritans were "amazed at the sexual restraint of Indian men, who never raped their captives." ${ }^{87}$ Brigadier General James Clinton of the Continental Army told his troops in 1779 , "[b]ad as the savages are, they never violate the chastity of any women, their prisoners." 88 Furthermore, historical records include far more 


\section{Deer}

accounts of sexual abuse of indigenous women by Europeans than accounts of European women by indigenous men. ${ }^{89}$ Rape, when it did occur, was severely punished by Native justice systems. Even Europeans who wrote disparagingly about Native people noted that Native people abhorred sexual violence. One such account comes from George Croghan, who testified about Indians in the Middle Atlantic colonies in the late $18^{\text {th }}$ century: "I have known more than onest thire Councils, order men to be putt to Death for Committing Rapes, wh[ich] is a Crime they Despise." 90

The sexual autonomy of indigenous women is a recurring theme in many of the accounts written by early European observers. Women's sexual choices were respected by the community, in contrast to the European models of justice that served to limit, penalize, and punish sexual choices of women. The notion that Native women had autonomy over their bodies (as compared to European women), is expressed in both oral tradition and the observations of European explorers. There is ample evidence to indicate that many Native women retained control over their sexuality. ${ }^{91}$ Diron D'Artaguiette, a Frenchman, wrote that young Native girls "are the mistresses of their own bodies." 92 Mark St. Pierre and Tilda Long Soldier write, "[a]mong the Lakota, the woman owned her body and all the rights that went with it." This indigenous conception of sexual autonomy was no doubt linked to women's roles as powerful and intelligent beings.

Europeans often imposed their own expectations and standards for appropriate female sexuality on tribal people. ${ }^{94}$ In Spanish law, for example, women were considered to be the legal subjects of their fathers, brothers, or closest male relative. ${ }^{95}$ French Jesuits, who were the primary European contact for many tribal nations, were "baffled and sometimes horrified" by the sexual and political autonomy exhibited by indigenous women. ${ }^{96}$ Many Europeans were alarmed by the powerful role played by Native women within their nations and efforts were made to reduce the status of Native women through numerous means. ${ }^{97}$ Missionary records from throughout the continent indicate that many religious groups placed a strong emphasis on restricting and punishing Native women for expressing independence and sexual autonomy. ${ }^{98}$ Indeed, much of Anglo-American rape law is grounded in attempts to preserve the chastity and sexual dependence of women. ${ }^{99}$ Through the process of assimilation and acculturation, many of these European constructs of gender and sexuality have become incorporated into some contemporary indigenous communities. Reclaiming an indigenous jurisprudence of rape, therefore, may require an examination of tribal conceptions of sexuality, independence, and autonomy. 


\section{B. The Colonization Parallels}

war. ${ }^{100}$ Sexual violence has been described as inextricably linked to conquest and as a weapon of war. However, these new legal constructs are not a response to a new phenomenon. Indeed, sexual assault and use of women's bodies in war has been a facet of the human condition for thousands of years. The conquest of the North American continent is not immune to this history. There are numerous examples throughout the recorded history of contact between Europeans and indigenous peoples that include acts of sexual violence and rape. ${ }^{101}$ Historical documentation of rape perpetrated by European men against Native women date back as far as Columbus. ${ }^{102}$

A socio-historical review of sexual assault of Native women in the United States reveals a strong relationship between the seizure of tribal lands and the seizure (rape) of Native women. Even the act of colonization itself has often been described using sexual metaphors. Images of Native women were used to represent America, "upon whose passive, receptive body European colonists could carry out their project of exploitation and domination." 103 The language used to describe imperial conquest is often similar to the language used to describe sexual violence. The land itself was often referred to in feminine terms, often praised for its "fertility" or "virginity."104 The Spanish explorers often wrote of having "intercourse" with the land. ${ }^{105}$ Possession was also an integral part of the European discourse of "discovery." The dehumanization of Native peoples, which was used to justify the seizure of land, is similar to the dehumanization of women, used to justify or minimize the harm of sexual violence. Consider the following passages; the first describes the justification for colonization, and the second describes the justification for sexual violence.

- "The law adopted the fantasy of Indians as uncivilized and savage, the opposite of American, and this fiction provided a justification for denying their natural rights, taking control of their land and denying their independence." 106

- "The perceived "lusty" and libertine nature of Indian women was often used as an excuse for rape by "Christian" soldiers." 107

Colonization and sexual violence, then, share a common history and a common language of dehumanization, power, dominance, and conquest. ${ }^{108}$ Although women of all races experience sexual violence, the high rate and elevated violence experienced by Native women (and other indigenous women) indicate that the history of conquest and seizure has a disparate impact on the indigenous populations. 


\section{Deer}

\section{Rape as a Tool of Colonization}

Numerous historians have documented actual incidents of rape being used as a weapon to control and colonize Native peoples. For example, many so-called Native "rebellions" or "outbreaks" have been linked to the sexual assault of Native women. ${ }^{109}$ Native men in many nations retaliated against the sexual assault of women. Historian Virginia M. Bouvier has documented the links between rape of Indian women and Indian "revolts" against Spanish missions in the $18^{\text {th }}$ century. ${ }^{10}$ Letters from priests in the San Diego region, for example, indicate that the rapes of indigenous girls and women in four nearby rancherias by Spanish soldiers were a cause for great concern. ${ }^{111}$

Sexual violence was often linked directly to some of the most destructive acts against Native peoples of the United States, such as forced removal and relocation in the Trail of Tears ${ }^{12}$ and the Long Walk ${ }^{113}$. Native women were raped by white men during encounters such as the Gold Rush. ${ }^{114}$ These documented accounts reflect that sexual assault of Native women by non-Native men was not isolated to any particular geographic area, but was widespread, from the Northeast ${ }^{115}$, to the Plains, to the Southwest. The Anglo-American legal system rarely, if ever, responded to these incidents. ${ }^{116}$ The widespread rape of Native women had numerous effects upon indigenous nations, including the spread of sexually-transmitted disease. ${ }^{117}$ The systemic culture of sexual violence also resulted in numerous cultural traumas. Psychologist Leslie E. Korn notes, "The invasion of development disconnects people from their land and its plentitude of resources just as rape leaves and individual disconnected from her and others and in somatic, psychic and spiritual pain." Consider this passage from historian James A. Sandos:

Priests taught Indians patriarchy and, in the process, lowered the status of Indian women within Indian culture. Such devaluation was further compounded by the shameful rape of Indian women by Spanish and Mexican soldiers and settlers. Angry Indian men were killed for their opposition to the rape of tribal women. Partly to protect them from soldiers, priests in the missions had unmarried Indian women above the age of seven locked together at night in a room known as the monjería (nunnery) to preserve their chastity. Female separation from the extended family must have been emotionally painful. Confining them in a group, moreover, spread infectious disease, making them more vulnerable to microbes than men. All of these changes created tension and required personal adjustment, profoundly difficult for some, less so for others. ${ }^{119}$ 
Widespread rape may also have had an impact in the balanced gender roles, which existed in many indigenous societies. At least one historian has postulated that many tribal social and economic structures were disrupted as a result of rape by outsiders. ${ }^{120}$ For example, in the Paiute culture, women served as the primary food gatherers, and were unable to continue in this capacity because it left them without protection from the predatory acts of the settlers. ${ }^{121}$ Ultimately, the incidents of sexual violence against Native women served as a tool of governmental destruction and assimilation. Antonia Castañeda notes, "sexual violence functions as an institutionalized mechanism for ensuring subordination and compliance. It was one instrument of sociopolitical terrorism and control - first of women and then of the group under conquest." 122 Environmental destruction and degradation have also been linked to the psychological attack on the female. ${ }^{123}$

\section{Other Forms of Sexual Violence}

Sexual violence is often linked to conquest and genocide precisely because of its effect on reproduction. ${ }^{124}$ The role of woman as a mother was often a critical component of identity within most indigenous communities. ${ }^{125}$ The history of colonization in America includes numerous references to the motherhood of indigenous women. Even seemingly consensual sexual relationships and marriage between Native women and European men were not immune from a context of power and control. Historian Albert Hurtado writes that Native women often married or had sexual relationships with European men as a "survival strategy."126 Indeed, descriptions of historical accounts of sexual relationships between European fur traders and Native women sound remarkably similar to descriptions of modern-day sex trafficking. ${ }^{127}$

Widespread sexual violence also impacted fertility and birth rates. Priests and missionaries recorded that Native women chose to induce abortions or otherwise restrict their fertility in communities where sexual violence had become commonplace. Sarah Winnemucca, a Paiute leader, wrote in 1883: "My people have been so unhappy for a long time they wish now to disincrease, instead of multiply. The mothers are afraid to have more children, for fear they shall have daughters, who are not safe even in their mother's presence." 128 Later, in the $20^{\text {th }}$ century, United States policies resulted in widespread forced sterilization of Native women. ${ }^{129}$

Another method of introduction of sexual violence into tribal communities is rooted in the boarding school era, which began in 1869. Under the authority of the United States government, Native children were forcibly removed from their homes and taken to boarding schools at a rate exceeding $70 \%$ in some communities. This era brought a new level of sexual violence to indigenous communities in the form of 


\section{Deer}

sexual abuse of children. ${ }^{130}$ The extent to which children in boarding schools were raped may never be fully known, but the volume of anecdotal accounts from survivors would lead one to believe that some boarding schools were fraught with sexual abuse. $^{131}$ Certainly, there are documented efforts to control the sexuality of Native girls, which resulted in more secrecy and shame in tribal communities. ${ }^{132}$

It can be argued that indigenous women who are raped in the United States today face a legacy of laws that have historically encouraged the systemic rape of Native women. It is within this context that tribal nations must respond to sexual violence -- a balance of historical insight with contemporary understandings. This legacy of sexual abuse in tribal communities must be explored and documented in order to reclaim authority and understanding about the contemporary context in which rape occurs.

\section{Framing an Indigenous Perspective}

Contemporary indigenous women have intuitive knowledge that tribal governments did not traditionally condone or tolerate sexual violence. In conversations with Native women, almost all of them are certain that their nation traditionally had strong responses to the crime, and that sexual violence is not in accordance with traditions or customary law. However, contemporary tribal laws and policies do not necessarily reflect this strong anti-rape sentiment, and much work will need to be done in order to reclaim the legal philosophy that once served to protect and honor women.

In order to develop an effective contemporary response to rape at the tribal level, it is first necessary to deconstruct the Anglo-American definitions of rape and develop an independent legal framework around sexual violence. As noted by Steven Russell: "Indians enter the conversation about law in need of an externalist critique."133 Native people need to develop an independent construction of legal wrongs as well as culturally appropriate sanctions. The resulting statutory construction may look significantly different from the Anglo-American model, insofar as it frames the issue from a particular Native community's perspective. In the following exploration of indigenous conceptions of rape law, two assumptions are made. First, the notion that indigenous nations have never had a sophisticated response to crimes against women is rejected. Second, the historical context in which sexual violence occurs will necessarily inform and shape a contemporary tribal response. There will not be a singular response to sexual violence; instead, each tribal government must develop its own unique response to the crime of rape, although dialogue among tribal nations may be helpful in this regard.

At the outset, it should be noted that developing an indigenous model of antirape jurisprudence will not necessarily resemble a typical feminist approach to the 


\section{Indigenous Jurisprudence of Rape}

topic. Feminist theory, ${ }^{134}$ particularly liberal feminism, has elements that can actually conflict with or contradict indigenous philosophies. This is not to say that indigenous societies are oppressive or patriarchal -- rather, these cultures have traditionally depended on gender balance, wherein each gender has separate roles and functions, both honored equally ${ }^{135}$.

An effective rape response in Indian country will not originate from a simple blending of tribal law with feminist theory. Given the unique nature and structure of tribal legal systems, and the unique relationship between colonization and sexual violence, developing an indigenous jurisprudence of rape requires deconstructing the male-centered, colonial, Anglo-American model. Nadera Shalhoub-Kevorkian writes, "[c]opying models of intervention without in-depth examination of their applicability to a given social setting might not only inflict additional pain and problems, but might also imprison helpers in unrealistic and non-applicable theories and methods."136 Simply replicating the Anglo-American model without discussion will fail to address the unique nature and context of sexual violence as experienced by Native women. In other words, if tribal governments rely on the Anglo-American legal conceptions of sexual violence as a model, the sexual violence crisis may actually be exacerbated rather than alleviated. Laura Hengehold writes that "[i]nstitutional definitions of the traumatic event, including the range of possible consequences for both victim and perpetrator, enter into the trauma of a sexual assault."137

Because sexual violence has been inextricably linked to colonization and imperialism, and has served as a means by which to terrorize and subdue indigenous nations, then the indigenous re-definition of rape must empower the tribal governments to assert control over the response to rape and the promotion of justice on their own terms. ${ }^{138}$ However, efforts to frame an indigenous jurisprudence of rape should not be merely a backward glance at legal systems as they existed 500 years ago. ${ }^{139}$ Rather, the efforts should be grounded in a contemporary understanding of the crime, informed and contextualized by historical analysis. As Robert Allen Warrior notes, “. . . the success or failure of American Indian communal societies has always been predicated not upon a set of uniform, unchanging beliefs, but rather upon a commitment to the groups and the groups' futures." 140 Tribal nations attempting to address the crime of sexual violence will be successful only by incorporating contemporary views and voices into the tribal judicial systems.

Reshaping and reclaiming tribal responses to sexual assault will necessitate an exploration of two areas -- substantive rape law (defining and criminalizing sexual assaults) and procedural law. In the substantive arena, an indigenous response to rape may require development and reform of contemporary tribal sexual assault codes. In addition, tribal governments may wish to re-evaluate the process and methods through which crimes of sexual violence are adjudicated. Some of this work may have already been addressed in the context of child sexual abuse. 


\section{Deer}

Though tribal nations are limited in their ability to prosecute sex offenders, ${ }^{141}$ there are few legal barriers to developing laws and policies regarding education, prevention, and services for survivors of crime. Indigenous nations may wish to explore, for instance, developing statutory provisions that mandate sexual assault prevention programs in all tribal schools and programs. Moreover, tribal governments will find it necessary to address sexual violence both inside and outside the criminal justice system. Because of the high percentage of perpetrators who are not tribal members, tribal governments may wish to enact a number of civil remedies and procedures that will provide some means of justice for survivors of assaults perpetrated by non-Indians.

Before the more specific statutory and procedural issues can be approached, however, it is important to establish a legal "theory" of rape that forms the basis of the response. A legal theory provides a foundation for a system's legal responses because it explains why the act itself is wrong. ${ }^{142}$ Legal scholars have analogized rape to other areas of law, such as contract law ${ }^{143}$ or torts law. ${ }^{144}$

Legal philosopher Keith Burgess-Jackson identifies three major theories of sexual assault: conservative, liberal, and radical. ${ }^{145}$ The conservative theory, which includes historic English and Anglo-American rape law, analogizes rape to a kind of "trespass to chattels," wherein the perpetrator (usually a man), appropriates and uses the property (usually a woman or girl) of another male. ${ }^{146}$ The liberal theory constructs rape as a kind of "battery," wherein the perpetrator offends another person with unlawful touching. ${ }^{147}$ The radical theory views rape as an illegal "degradation," wherein the perpetrator causes a lowering in the victim's status as a person in the larger society. ${ }^{148}$

While these theories are helpful in classifying most of the existing legal scholarship on rape, none of these theories are necessarily comprehensive in their explanation of the experience of rape victims. Scholars have already suggested that a new theory of rape is needed in order to fully articulate the experiences of survivors. ${ }^{149}$ Hengehold notes that:

[T] he act of "defining" rape necessarily raises difficult questions, including ... whether and how the individual's search for a "just" recovery should mirror a movement's hope for wider forms of social justice, and what conception of the traumatic event enables feminists to link the level of the political and that of the existential without assuming the role of "expert discourse" vis-à-vis the women they hope to empower. ${ }^{150}$ 
With these thoughts in mind, there is a fourth theory of rape: an indigenous theory of rape. This indigenous theory transcends the limitations of the nonindigenous theories by conceiving of rape as an unlawful "invasion" of the body, mind, and spirit. This theory allows the resulting legal system to address the crime of sexual violence holistically -- that is, as a crime against a person in the context of her entire self. Therefore, the theory could conceivably apply to any survivor of sexual violence -- not just indigenous survivors. Where the liberal theory concentrates solely on the physical (body) aspect of the crime, and the radical theory concentrates solely on the social (political) aspect of the crime, this indigenous model allows the entire experience of the victim to be acknowledged. In short, rape is conceived of as a violation of a person's humanity.

Tribal nations in the United States are in a unique position to develop this theory of rape in contemporary legal thought, because of their position as survivors of invasion on a massive and extended scale. Because tribal legal systems are themselves "survivors" of an invasion, tribal law can conceptualize the experience of survivors of rape in a way that would be difficult for the dominant legal system to do. Additionally, indigenous legal theory generally brings a more holistic approach to jurisprudence, as compared to the Anglo-American system, which compartmentalizes and fractionates human experience.

The indigenous theory of rape will manifest itself differently for each tribal nation -- therefore the accurate term would be indigenous "theories." Using unique history, language, and government structure, each nation may conceive of rape in slightly different ways. Identifying sources and foundations for building a discourse about the indigenous theories of rape is critical. The following section explores several possibilities for starting points in development of indigenous theories.

Developing an indigenous jurisprudence of rape is not necessarily only relevant to tribal governments. Indeed, its application has the potential to also inform and shape mainstream social change movements.

\section{A. Resources}

Contemporary tribal rape law will be most effective if rooted in tradition and grounded by a uniquely indigenous philosophy that understands the experience of rape on both a micro (individual) and macro (community) level. Tribal nations have an abundance of resources from which to draw in developing a theory of rape. These resources include stories, history, language, and the shared experiences of community members. Below are five possible resources for research and discussion by individual tribal nations attempting to address the appropriate response to rape. 


\section{Deer}

\section{Stories of Survivors}

The power of individual women's stories of surviving sexual assault should not be underestimated. Indeed, there are accounts of the power of a single woman's story to affect change within her tribal government. ${ }^{151}$ Reclaiming and understanding these stories is critical in developing a meaningful legal structure that is responsive to the real experiences of contemporary indigenous women. The stories of survivors are stories of despair and pain but also strength and survival.

Tribal legislative bodies may wish to convene a panel of survivors of sexual assault from the community. This panel can describe to the tribal lawmakers how the current system(s) responded to the crime (if at all), and whether the current system is providing justice. In addition, survivors could provide guidance to lawmakers as to how the legal response can be developed in a victim-sensitive way. Keeping in mind that most tribal nations' constitutions are very protective of the rights of the accused, tribal nations may want to work with survivors and advocates to assure that victims' privacy, rights, and well-being are protected.

Philosopher Ann J. Cahill writes of the importance of defining rape "not as something a man does, but something which a woman experiences."152 Native women's voices carry the truths about rape in Indian country. Sexual violence is a theme found in poetry, ${ }^{153}$ fiction, ${ }^{154}$ and non-fiction written by Native women. The voices of women who have survived sexual violence can form the foundation of contemporary tribal responses to rape. Grounded in the reality of the individual horrors of the crime, Native women who choose to describe their experience and survival provide significant information as to the appropriate legal response. These voices are continuations of the protests, which began centuries ago.

Listening to women's stories is in keeping with the ancient tradition of considering a woman's perspective as a separate entity. This school of thought does not deny that men can be victims of sexual violence, but does acknowledge the value of learning and teaching from a gendered perspective. Given that women in many tribal cultures have unique and specific roles, it follows that they may have unique and specific legal knowledge about rape. It is not unusual for women to carry particular unique knowledge, which is specific to the experiences of women. ${ }^{155}$

\section{Ancestral Teachings}

Contemporary tribal nations can also draw upon the strengths of historical leaders who spoke out in protest against sexual assault. Records of indigenous perspectives on sexual assault are found in the writings and speeches of historical 
figures such as Sarah Winnemucca and Yankton Dakota Chief Struck-the-Ree. A Paiute woman, Sarah Winnemucca was an Indian rights activist in the late nineteenth century. In her autobiography, Life Among the Piutes, Winnemucca wrote about specific instances of sexual violence against women in her community, including her younger sister. ${ }^{156}$ Yankton Dakota leader Struck-the-Ree spoke to Congress in 1867 about the experiences of the women in his nation, who were forced or coerced into sexual relationships with United States soldiers. ${ }^{157}$

These historical figures provide contemporary tribal nations with a sense of continuity and leadership in the resistance to sexual violence. Clearly, for leaders such as Winnemucca and Struck-the-Ree, sexual violence was not acceptable or tolerable in any form. Each indigenous culture has its own historical figures, legends, or writings that can be incorporated into the contemporary understanding.

\section{Tribal Customary Law}

There is ample evidence that rape has traditionally been defined as criminal behavior by tribal nations. Case law from some tribal nations indicates that the contemporary tribal judiciary recognizes that rape violates tribal common law. ${ }^{158}$ Many tribal nations, though, are struggling with the incorporation and codification of traditional beliefs into the contemporary legal systems. ${ }^{159}$ One method of incorporating traditional beliefs into the contemporary context is to engage in a rigorous examination of tribal oral histories, anthropological and linguistic studies, and interviews with tribal elders. ${ }^{160}$

In developing a critical comparative analysis between an indigenous jurisprudence and the Anglo-American jurisprudence of rape, simply reviewing the history of a tribal nation's written laws may provide some guidance as to the traditional approach to rape. A chronology of sexual assault laws in the Muscogee (Creek) Nation reveals some interesting clues as to how the tribal legal system may have traditionally conceived of rape. In reviewing the early anthropological accounts of Muscogee (Creek) culture, very few references are made to sexual violence. However, there is evidence that the Creeks always considered it wrong to physically hurt a woman. ${ }^{161}$ Interestingly, one of the first written codes for the Creek Nation (1824) included the following provision for rape:

And be it farther enacted if any person or persons should undertake to force a woman and did it by force, it shall be left to woman what punishment she Should satisfied with to whip or pay what she say it be law. ${ }^{162}$ 
Deer

When compared with European and American laws on rape in 1824, and even later Creek laws regarding sexual assault, this early law is quite unique. The 1824 law, which appears to give the victim of rape control over the punishment, differs vastly from later Creek laws on rape, in which the tribal court had jurisdiction and the penalties were clearly defined by the government. In 1867, another criminal code was adopted by the national council (which was more heavily influenced by the AngloAmerican system): "Be in enacted, That should any person be convicted of rape, he shall for the first offense receive fifty lashes, for the second offense he shall suffer death." 163 One can infer that the 1824 code bears closer resemblance to the traditional Creek law. This would be consistent with the common theme in Creek jurisprudence of centering the judicial system on restoration. It is also possible that the very nature of the crime itself also focused on the victim -- and that the question of fact (whether or not rape had occurred) was controlled by the testimony or the victim. Note that the later 1867 law does not mention the victim at all.

\section{Traditional Beliefs / Oral Traditions}

Stories, ceremonies, and spiritual teachings have always played a central role in indigenous responses to crime. ${ }^{164}$ When determining the best way for any particular community to respond to sexual violence, it will be beneficial to revisit some of these stories and beliefs. For example, many cultural beliefs include strong social sanctions against certain kinds of sexual behavior, such as incest. There is often shame and ostracism associated with perpetrating sexual crimes, such as the philosophy among the Apache that a rapist "does not even deserve to be called a man, a human being."165 Traditionally, women passed on information concerning sexual matters through stories, ceremonies, and songs. The loss of these practices (through criminalization of tribal spiritual and cultural practices) has meant a greater vulnerability to exploitation and victimization. Sexually explicit stories often addressed issues of inappropriate, abusive, or criminal conduct, as well as taboos. ${ }^{166}$

Accounts of rape and the traditional response can be found in numerous oral traditions and histories; sometimes they are not obvious and may not be apparent to legal theorists or contemporary tribal attorneys. The following examples are but a few of the accounts I have discovered in researching the issue of rape in indigenous thought. I do not presume to articulate a fully accurate interpretation of these accounts; rather I provide them as examples and beginnings of research and dialogue that should happen within each tribal community as the governments reclaim their jurisdiction over crimes of sexual violence against women. ${ }^{167}$ 


\section{a. Ani-Kutani (Cherokee) ${ }^{168}$}

The Ani-Kutani are described in Cherokee oral and written tradition as a class or clan made up of very powerful individuals. It is not clear from the history when the Ani-Kutani existed; but they are almost always described as a family or clan that exerted much spiritual power and control over others. Most accounts of the AniKutani refer to an incident or incidents of sexual impropriety against one woman or several women in the community. This inappropriate sexual behavior instigated a revolt against everyone who was associated with Ani-Kutani. Every last member of the Ani-Kutani was slain and today the clan or group has ceased to exist.

The story of the Ani-Kutani may provide powerful lessons and guidance for indigenous nations today. First, there is a clear understanding that sexual violence stems from an abuse of power and dominance. The clan members, who were once revered leaders, began to abuse and manipulate their power for personal gain. Second, the extermination of the Ani-Kutani provides a warning and lesson for those who would commit such a crime; that for violating women, the perpetrator jeopardizes not only his own life and liberty, but also that of his clan. Depending on the particular interpretation and methodology, a story such as this could have profound influence on the development of contemporary sexual violence jurisprudence.

\section{b. Tale of the Raped Maiden (Ojibwa) ${ }^{169}$}

This Ojibwa tale, published in 1906 by an anthropologist, is an empowering story of the worth and value of women. The story was told by an Ojibwa elder named Mrs. Chatfield in 1894. The main protagonist in the story, an Ojibwa woman, was raped by members of a warring tribe. In the aftermath of the rape, this woman becomes revered among her own people, becoming both a medicine woman and a warrior. She is clearly held up to be a strong and powerful woman.

This imagery of the survivor of sexual assault in this story is in sharp contrast to many widely held Western beliefs about women who have been raped as stigmatized, shamed, or soiled. Building a legal response on the strengths and power that women survivors of sexual violence bring to their community will provide safety and accountability. It also addresses the profound shame and embarrassment that stems from an Anglo construction of rape law, in which a virgin is defiled. As noted by one Ojibwa traditional healer, the dominant cultural view is that society needs to protect women because they are weak. ${ }^{170}$ As this story and other teachings demonstrate, the "Indian way is to protect women because they are strong."171 
Deer

\section{c. Taa'ii' 'Ti' and the Russians (Gwich'in Athabascan) ${ }^{172}$}

This story originates from Alaska, and was recorded by Johnny Frank in 1971, later transcribed, translated, and published by the Alaska Native Language Center at the University of Anchorage, Fairbanks. This story speaks to a tribal leader's response to sexual violence perpetrated by outsiders. It is not clear from the text itself when and where the incidents occurred. The story centers around the leader of the village, Taa'ii' Ti', and how he responded to the molestation of the community women by Russian sailors. The Russians who sexually abused the women in the village were warned about their behavior, and when they continued, Taa'ii' Ti' killed all but four of the men. This story shows not only the gravity of the crime, but also the immediate and swift response to the victims and the importance of strong leaders. The assertion of jurisdiction over the non-Indian Russians also shows the strong inherent sense of sovereignty -- and the importance of authority over outsiders.

\section{B. Challenges to Developing an Indigenous Jurisprudence}

For all nations, defining and executing laws to protect women and children are central to the conception of sovereignty. The issue involves more than protecting individuals from harm -- but about maintaining safety and well-being for the entire community. The strength of the anti-rape sentiment in a tribal government will illuminate the strength and resolve of the entire community. However, the development and articulation of the anti-rape sentiment will be difficult and challenging for many communities. The intellectual exercise of developing a theory of jurisprudence of sexual assault is rational and unemotional -- but the subject matter itself is intensely and overwhelmingly personal. ${ }^{173}$ Because sexual violence has been so pervasive and yet so hidden in most tribal communities, initial attempts to construct a conversation about the appropriate response to rape may result in highly emotional and painful discussions. This phenomenon, I contend, is absolutely vital and necessary to a long-term plan for the development of a contemporary response to rape. For instance, the impact of sexual assault is so damaging that even the drafters of a new tribal law on rape may have much processing and healing to do themselves before they can address the topic in a clear and empowering way. There is also the reality that perpetrators may also hold positions of leadership and influence. ${ }^{174}$ Because of these circumstances, ceremonial and traditional healers may need to be at the forefront of the discussion about rape law reform at the tribal level.

Raising the topic of sexual violence within tribal communities may result in highly emotional and sensitive responses. In many contemporary indigenous communities, there are likely generations of sexual assault survivors who have 


\section{Indigenous Jurisprudence of Rape}

remained silent about their experiences. Denial and secrecy have incredible power over victims. ${ }^{175}$ In addition, there are likely numerous cases, which have gone unrecognized and many perpetrators who have gone unpunished. Sherry L. Hamby notes that, "[c]lose-knit communities can offer enhanced support and other advantages, but the reduced privacy can be a problem for stigmatized issues such as sexual victimization." 176 Therefore, it is critically important that local, indigenous grassroots women's advocates be a central part of the dialogue. Women's advocacy programs, especially those grounded in grassroots organization, can provide support and encouragement for survivors of sexual assault, and provide a voice for those who cannot speak.

Women's advocates bring other skills to the table as well. For example, advocates have unique perspectives on the current legal response to rape, and can provide feedback as to weaknesses in the system. They also may have more accurate statistics on the rate of sexual assault in a particular community. It will be difficult, if not impossible, for tribal communities to be able to address sexual violence head-on without the inclusion and leadership of such advocacy programs.

\section{Conclusion}

"Sharing knowledge is... a long-term commitment."

$$
\text { Linda Tuhiwai Smith }{ }^{177}
$$

Protecting and supporting the citizenry is a central component of sovereignty. It has become clear that Native women cannot depend on external systems of justice to provide justice and accountability for the high rates of sexual violence they experience. Therefore, tribal governments must make efforts to restore and strengthen their ability to address these crimes. Contemporary indigenous leaders have worked tirelessly to reclaim and redefine what it means to be sovereign nations, but the pervasiveness and destructive power of sexual violence against Native women continues unabated. Perhaps it is at the intersection of federal Indian law and rape law reform that the community solutions will become better illuminated. Part of de-colonizing the mind and body is to send a message that as tribal nations we will no longer tolerate the invasion of our communities through the violation of our grandmothers, our clan mothers, our life-givers, our sisters, or our daughters -- from outsiders or those within our community. As ancient sovereign nations, we must look to our histories, beliefs, resources, and experiences to reclaim safety and empowerment for all women. 
Notes

* Staff Attorney, Tribal Law and Policy Institute, West Hollywood, California. Citizen, Muscogee (Creek) Nation of Oklahoma. This essay developed from a speech delivered at the 2003 Tribal Law \& Governance Conference hosted by the Tribal Law and Government Center at the University of Kansas School of Law. Thanks to Professor Stacy Leeds for organizing the conference and inviting me to speak. Thanks also to Jerry Gardner \& Bonnie Clairmont, whose support and encouragement made this article possible.

1. Joy Harjo \& Gloria Bird, Introduction, in REINVENTING THE ENEMY's LANGUAGE 19, 21-22 (Joy Harjo \& Gloria Bird eds., 1997).

2. The vast majority of sexual assaults are committed by men against women. Lawrence A. Greenfeld, U.S. Dep't of Justice, Sex Offenses and Offenders: An Analysis of Data on Rape and Sexual Assault 24 (February 1997). For this reason, I will use gender-specific language throughout this article.

3. Throughout this article, I use the term "rape" to refer to a system's legal treatment of sexual aggression as a crime. Rape may have many different degrees and names in any particular jurisdiction, including sexual assault, sexual abuse, sexual battery, etc.

4. See Christine Boyle, What Makes "Model" Sexual Offenses? A Canadian Perspective, 4 BUFF. CRIM.L. REV. 487, 492 (2000).

5. Because very few legal scholars have addressed the topic of rape of indigenous women, this article relies upon many non-legal sources in developing this article, including sociology, history, philosophy, and news reports.

6. See, e.g., Elizabeth M. Iglesias, Rape, Race and Representation: The Power of Discourse, Discourses of Power, and the Reconstruction of Heterosexuality, 49 VAND. L. REV. 869

(1996); Gail Elizabeth Wyatt, The Sociocultural Context of African American and White American Women's Rape, 48 J. SOC. IssUeS 77 (1992); Lily D. McNair \& Helen A. Neville, African American Survivors of Sexual Assault: The Intersection of Race and Class, 18 WOMEN \& THERAPY 107 (1996). The invisibility of Native issues is not unique to the context of sexual assault. See Steve Russell, A Black and White Issue: The Invisibility of American Indians in Racial Policy Discourse, 4 GEO. PUB. POL'Y REV. 129 (1999).

7. See Patricia D. Rozee \& Mary P. Koss, Rape: A Century of Resistance, 25 PSYCHOL. WOMEN Q. 295 (2001).

8. Andrea Smith, Not an Indian Tradition: The Sexual Colonization of Native Peoples, 18 HyPATIA 70 (2003). The contemporary anti-rape movement, having its origin in the white feminist movement, often misses crucial issues for Native women and women of color. See, e.g., ALISON EDWARDS, RAPE, RACISM AND THE WHITE WOMEN'S MOVEMENT: AN ANSWER TO SUSAN BROWN MILLER (Sojourner Truth, 1988).

9. Indeed, as Bethany Ruth Berger points out, federal Indian law scholars rarely, if ever, examine the impact of United States law on indigenous women. Bethany Ruth Berger, After Pocahontas:

Indian Women and the Law, 1830 to 1934, 21 AM. INDIAN L. REV. 1, 3-4 (1997).

10. Judith V. Royster, Oliphant and its Discontents: An Essay Introducing the Case for Reargument Before the American Indian Nations Supreme Court, 13 KAN. J.L. \& PUB. POL'Y 59, 61 (2003).

11. In fact, while Native people have been speaking out about sexual assault for hundreds of years, the past 10 years have seen a resurgence of Native women mobilizing in local and regionalcoalitions to demand an improved response to the violence they experience. Brenda Norrell, Native Women Are 


\section{Indigenous Jurisprudence of Rape}

Prey; Communities and Courts Fail Native Women, NEWS FROM INDIAN COUNTRY, Dec. 29, 2003, at 9.

12. Keith Burgess-Jackson, A Crime Against Women: Calhoun on the Wrongness of Rape, $31 \mathrm{~J}$. SoC.

PHIL. 286, 286-87 (2000).

13. Boyle, supra note 4 , at 492 .

14. GERALDINE MALONE, GENDER AND COLONIALISM 37 (1999)("It is extremely difficult to establish the extent of such violence because of a lack of research and because of the very strong pressures on women to keep silent about such crimes").

15. It is important to note that none of these surveys are sponsored and/or conducted by native Researchers or tribal nations.

16. See Lawrence A. Greenfeld \& Steven K. Smith, U.S. Dep't. of Justice, American Indians and Crime (1999); Callie Rennison, U.S. Dep't of Justice, Violent Victimization and Race, 1993-98 (March 2001).

17. Patricia Tjaden \& Nancy Thoennes, U.S. Dep't. of Justice, Full Report on the Prevalence, Incidence, and Consequences of Violence Against Women 22 (2000).

18. Greenfeld \& Smith, supra note 16 , at 3.

19. Peter Hovmand, Michigan Violence and Intentional Injury Prevention Program, 2 SEXUAL ASSAULT SURVEILLANCE SYSTEM 3 (July 1999); LUCY BERLINER, OFFICE OF CRIME VICTIM ADVOCACY, SEXUAL ASSAULT EXPERIENCES AND PERCEPTIONS OF COMMUNITY RESPONSE TO SEXUAL ASSAULT: A SURVEY OF WASHINGTON STATE WOMEN 16 (Harborview Medical Center 2001).

20. Jim Maniaci, Rape Cases Increasing on the Reservation: Expanded Sex Offenders Tribal Web Site Planned, GALLUP INDEPENDENT, August 30, 2003.

21. See, e.g., Hannah S. Scott \& Rebecca L. Beaman, Sexual Assault Among Aboriginal and NonAboriginal Peoples in a Western Canadian City: A Case for Including Race When Collecting Crime Data, 1 ONLINE J. JUST. STUD. 5 (2003); Elizabeth C. Gomes, Native Women and Sexual Assault: Their Patterns and Experiences (1995) (unpublished manuscript, on file with University of Windsor); Larissa Behrendt, Consent in a (Neo)Colonial Society: Aboriginal Women as Legal and Sexual 'Other', 15 AUSTL. FEMINIST STUD. 353 (2000).

22. See, e.g., Cathy Winkler, Rape Attack: The Ethnography of the Ethnographer, in FIELDWORK UNDER FIRE. CONTEMPORARY STUDIES OF VIOLENCE AND SURVIVAL, 155-184(Carolyn Nordstrom \& Antonious Robben, eds. 1995).

23. Claudia Card, Rape as a Weapon of War, 11 HYPATIA 5, 6 (1996).

24. See, e.g., Samuel H. Pillsbury, Crimes Against the Heart: Recognizing the Wrongs of Forced Sex, 35 LOY. L.A. L. REV. 845, 851 (2002).

25. Suzanne L. Barker-Collo, Reported Symptomatology of Native Canadian and Caucasian Females Sexually Abused in Childhood, 14 J. INTERPERSONAL VIOLENCE, 747, 757 (1999).

26. D.K. Bohn, Lifetime Physical and Sexual Abuse, Substance Abuse, Depression, and Suicide Attempts Among Native American Women, 24 Issues MENTAL HEALTH NURSING 333, 333 (2003).

27. Bernard Segal, Responding to Victimized Alaska Native Women in Treatment for Substance Use, 36 SUBSTANCE USE \& MISUSE 845, 851 (2001).

28. Jane M. Simoni, Shalini Sehgal, \& Karina L. Walters, Triangle of Risk: Urban American Indian Women's Sexual Trauma, Injection Drug Use, and HIV Sexual Risk Behaviors, 8 AIDS \& BEHAV. 33, 40 (2004). See also IRENE S. VERNON, KIILING Us QUIETLY: NATIVE AMERICANS AND 
HIV/AIDS 37-59 (Univ. of Neb. Press 2001).

29. Elsie B. RedBird, Honouring Native Women: The Backbone of Native Sovereignty, in POPULAR JUSTICE AND COMMUNITY REGENERATION: PATHWAYS OF INDIGENOUS REFORM 121 (Kayleen M. Hazelhurst ed., 1995).

30. See Leslie E. Korn, Community Trauma and Development, 5 FOURTH WORLD J. 1 (2002).

31. Roy Porter, Rape - Does it Have a Historical Meaning?, in RAPE: AN HISTORICAL AND SOCIAL ENQUIRY 216, 217 (Sylvana Tomaselli \& Roy Porter eds., 1986).

32. Michelle J. Anderson, Women Do Not Report the Violence They Suffer: Violence Against Women and the State Action Doctrine, 46 VILL. L. REV. 907, 924-925 (2001).

33. Sherene Razack, What Is to Be Gained by Looking White People in the Eye? Culture, Race, and Gender in Cases of Sexual Violence, 19 SIGNS: JOURNAL OF WOMEN IN CULTURE AND SOCIETY 894, 899 (1994). See also Kristin Bumiller, Rape as a Legal Symbol: An Essay on Sexual Violence and Racism 42 U. MIAMI L. REV. 75, 82 (1987).

34. See generally Razack, supra note 33.

35. CONG. REC. 2596 (1909), quoted in Shirley R. Bysiewicz and Ruth E. Van De Mark, The Legal Status of the Dakota Indian Woman, 3 AM. INDIAN L. REV. 255, 270 (1975).

36. Gray v. United States, 394 F. 2d 96, 101 (9th Cir. 1968).

37. Recent Case, Constitutional Law - Equal Protection of the Laws - Federal Statute Imposing Less Severe Penalty upon American Indian Who Rapes an Indian Woman than upon Other Rapists is Constitutional, 82 HARV. L. REV. 697, 702 (1969).

38. Smith, supra note 8, at 73.

39. See Callie Marie Rennison, U.S. Dep't of Justice, Rape and Sexual Assault: Reporting to the Police and Medical Attention, 1992-2000 (2002); Timothy C. Hart \& Callie Rennison, U.S. Dep't of Justice, Reporting Crime to the Police, 1992-2000 (2003).

40. S. Rep. No. 103-52, at 7-8 (1993).

41. Id. at 8 .

42. Id. at 1 .

43. Wendy Murphy, Rape and the Failure of Law Reform, 4 SeXUAL ASSAULT REP. 65, 65 (2002); Cassia C. Spohn, The Rape Reform Movement: The Traditional Common Law and Rape Law Reforms 39 JURIMETRICS J. 119, 129 (1999); Carole Goldberg-Ambrose, Unfinished Business in Rape Law Reform 48 J. OF SoCIAL IsSUES 173, 176 (1992). See also Kristen Bumiller, Rape as a Legal Symbol: An Essay on Sexual Violence and Racism, 42 U. MIAMI L. REV. 75.92 (1987) (suggesting that "[w]omen's truths are often lost in efforts for law reform.").

44. Susan Montoya Bryan, FBI Director Addresses Tribal Leaders, AP.Nov. 20, 2003 BC Cycle; Avis Little Eagle, Rape charge dropped, Standing Rock Angry, INDIAN COUNTRY TODAY, Mar 25, 1996. at A1; Mary Shepardson, The Status of Navajo Women, 6 AM. INDIAN Q. 149, 161 (1982) (noting that many "rape cases are declined by the U.S. Attorney and remanded to the tribal courts.") A 1996 Audit of Criminal Justice in Indian country acknowledged that there has been a history of poor communication between United States Attorney's Offices and tribal governments regarding prosecutorial decisions. As a result, "[v]ictims and their families believed that the offenders would never be punished for their crimes." U.S. Dep't of Justice, Office of the Inspector General, Criminal Justice in Indian Country, Audit Report 96-16, (September 1996). The Paiute-Shoshone Tribes of Ft. McDermitt have actually codified their concerns about federal prosecution in their law \& order code: "The Major Crimes Act provisions are enacted because of the poor prosecution record of federal authorities of such crimes on Indian reservations." FT. MCDERMITT PAIUTE- 
SHOSHONE TRIBES OF OR., AND NEV. LAW AND ORdER CODE, Ch. 7 (2003).

45. See, e.g., Report of The Executive Committee for Indian Country Law Enforcement Improvements, Final Report to The Attorney General and The Secretary of the Interior at appx. Tab B (1997) available at http://www.usdoj.gov/otj/icredact.htm\#TAB_B.

46. Dian Million, Policing the Rez: Keeping No Peace in Indian Country, 27 SoCiaL Justice 101, 102 (2000).

47. The Indian Health Service, the federal agency tasked with providing health care services throughout isolated and rural areas of Indian country, may be the only option for sexual assault forensic exam. I.H.S. has a history of hiring physicians who have been convicted of sex offenses (in violation of federal policy). In 2002, the Associated Press reported that at least two physicians with convictions for sexual violence had been hired and worked at Indian Health Service. See Matt Kelley, At Least 118 Federal Doctors Punished for Wrongdoing, AP, April 14, 2002, BC Cycle.(2002). More recently, a retired FBI internal investigator pled guilty to charges of sexual molestation. See ExFBI Official Admits Sex Assaults, AP, Feb. 18, 2004.

48. Kristin Littel, Office for Victims of Crime, U.S. Dep't of Justice, Sexual Assault Nurse Examiner (SANE) Programs: Improving the Community Response to Sexual Assault Victims 1, 5, March 2001.

49. See generally A Quiet Crisis: Federal Funding and Unmet Needs in Indian Country, U.S.

Comm. On Civ. Rights 2003, available at http://www.usccr.gov/pubs/na0703/na0204.pdf>

(hereinafter A Quiet Crisis). For a history of the issue, see JENNIE R. JOE, DOROTHY MILLER \& TRUdie NARUM, Traditional INDIAN ALLIANCE: THE DELIVERY OF HEALTH CARE To AMERICAN INDIANS IN TUCSON (1988).

50. The official national Indian Health Service manual does not contain any information regarding the importance of forensic exams on persons who report sexual assault. Indeed, the language from the Manual states that in cases of sexual abuse, "[I]t is IHS policy to perform only medically related care and treatment." (emphasis added) Indian Health Manual, Part 3, Ch. 13, § 3-13.8, available at http://www.ihs.gov/PublicInfo/Publications/IHSManual/Part3/pt3chapt13/pt3chpt13.htm\#8.

51. See generally Carole Goldberg-Ambrose, PlanTING TAIlfEATHERS: TRIBAL SURVIVAL AND PUBLIC LAW 280 (American Indian Studies Center 1997).

52. Mending the Sacred Hoop, Jurisdictional Issues Complicate Response to Sexual Assault for Tribes Under PL280 Status, FALL/WINTER THE RESOURCE, 2, 12 (2003).

53. André Rosay \& Robert H. Langworthy, Alaska J. Statistical Analysis Center, Descriptive Analysis of Sexual Assaults in Anchorage, Alaska, Final Report to the Bureau of Justice Statistics 5 (October 2003).

54. Esaúl Sanchez, Peggy Reeves Sanday Takes a Historic Look at Rape and Accountability, THE COMPASS (March 19, 1996) available at http://www.upenn.edu/pennnews/features/1996/031996/sanday.html.

55. See generally 18 U.S.C. $\$ 1153$ (2004).

56. See Robert N. Clinton, Criminal Jurisdiction Over Indian Lands: A Journey Through a Jurisdictional Maze, 18 ARIZ. L. REV. 503, 526 (1976). Note that child sexual abuse was not included in the MCA until 1986. Larry EchoHawk, Child Sexual Abuse in Indian Country: Is the Guardian Keeping in Mind the Seventh Generation? 5 N.Y.U J. OF LEGIS. \& PUB. POL'Y 83, 107 (2001).

57. Wetsit v. Stafne, 44 F.3d 823, 824 (9th Cir. 1995).

58. Letter from Ross O. Swimmer, Assistant Secretary of Indian Affairs, to Peter J. Sferrazza (Apr. 
1987) (on file with author).

59. See, e.g., 18 U.S.C. $\$ 1162(2004)$.

60. See U.S. Dep't of Justice, Office of Tribal Justice, Concurrent Tribal Authority Under Public Law 83-280, (2000). See also J. Jimenez \& Soo C. Song, Concurrent Tribal and State Jurisdiction under Public Law 280, 47 AM. U. L. REV. 1627 (1998).

61. Carole Goldberg-Ambrose, Public Law 280 and the Problem of Lawlessness in California Indian Country, 44 UCLA L. REV. 1405, 1416 (1997).

62. U.S. v. Wheeler, 435 U.S. 313, 323 (1978); U.S., v. Lara, 124 S.Ct. 1628, 1630-1641 (2004). Interestingly, Wheeler concerned a statutory rape prosecution. Christopher B. Chaney, The Effect of the United States Supreme Court's Decisions During the Last Quarter of the Nineteenth Century 14 BYU J. OF PUB. L. 173, 177 (2000).

63. 25 U.S.C. $\S \S 1301-3(2000)$.

64. See, e.g., A Quiet Crisis, supra note 49, at 67.

65. Indeed, some tribal codes classify rape as a "felony" level crime, even though the tribal court cannot sentence an offender to more than 1 year incarceration for the crime. See, e.g., Chitimacha Comprehensive Codes of Justice, Title III, Ch. 2, Subchapter C, Sec. 206 (1990).

66. Stephen D. Eaton, Native American Crime Victims Deserve Justice: A Response to Jensen and Rosenquist, 69 N.D. L. REV. 939, 941 (1993).

67. Some tribal codes contain a banishment provision for sex crimes. See, e.g., Absentee-Shawnee Tribe of Indians of Oklahoma Criminal Code, Ch. 2, §. 231; Pawnee Tribe of Oklahoma Criminal Code, Title VI, Ch. 2, $\S 231$; The Cherokee Code: Published by Order of the Tribal Council of the Eastern Band of Cherokee Indians, § 14-50-13 (2000) (excluding non-tribal members from the reservation for failure to register as a sex offender).

68. 435 U.S. 191; 98 S. Ct. 1011 (1978).

69. See Judith V. Royster, Oliphant and Its Discontents, 13 KAN. J. OF L. \& PUB. POL'Y 59, 59 (2003); Peter C. Maxfield, Oliphant v. Suquamish Tribe: The Whole is Greater Than the Sum of its Parts, 19 J. CONTEMP. L. 391, 394 (1993); see Russell Lawrence Barsh \& James Youngblood Henderson, The Betrayal: Oliphant v. Suquamish Indian Tribe and the Hunting of the Shark, 63 MINN. L. REV. 609 (1979).

70. Matthew L.M. Fletcher, Sawnawgezewog: "The Indian Problem" and the Lost Art of Survival, 28 AM. INDIAN L. REV. 35, 55 (2003) Victor H. Holcomb, Prosecution of Non-Indians for Nonserious Offenses Committed Against Indians in Indian Country, 75 N.D. L. REV. 761, 761 (1999).

71. See Greenfeld \& Smith, supra note 18 at 15. Indigenous women in Australia also report a high level of sexual violence perpetrated by white men. See AILEEN MORETON-ROBINSON, TALKIN' UP TO THE WHITE WOMAN 170 (University of Queensland Press ed., 2000).

72. See, e.g., Bruce Miller, Contemporary Tribal Codes and Gender Issues, 18 AM. INDIAN CULTURE \& RES. J. 43 (1994).

73. See, e.g., Navajo Nation v. Yellow, 21 ILR 6036, 6036 (1994) (criminal charges dismissed on procedural grounds); Fort Peck Assiniboine v. Martell, Ft. Peck App. Ct., available at http://www.fptc.org/Appellate\%20Opinions/090.htm (1990).

74. Bill Donovon, Crime stats: Tuba City leads in murders, NAVAJO TIMES, Feb. 27, 2003, at A8.

75. Lisa J. Bond-Maupin, "Who Made the Code in the First Place?": Delinquency and Justice in an American Indian Community, 25 CRIME, L. \& SOCIAL CHANGE 133, 136 (1996); Gloria ValenciaWeber, Tribal Courts' Use of Non-Indian Law, 6 NATIVE AMERICAN L. DIGEST 0063, 0063 (1996) (noting that "[i]t is disturbing that some tribal codes are the wholesale adoptions of state law or the 
Code of Federal Regulations for Courts of Indian Offenses (CFR/CIO Courts) where the tribes' name has simply been substituted for the originating government").

76. For example, at least one tribal government has a "fresh complaint" requirement in its rape statute, requiring that victims of sexual violence report the incident to law enforcement within 30 days. No other crime in the tribal code imposes this requirement on victims. Sault Ste. Marie Tribe of Chippewa Indians, Subchapter 18, Sec. 71.1801 (1995).

77. See, e.g., San Ildefonso Pueblo Code, Title IV, Chapter 13, § 13.45 (1996).

78. See, e.g., Muscogee (Creek) Nation Code Annotated, Title 14, § 2-314.

79. Sex Offender Registration Now Required, CONFEDERATED UMATILLA JOURNAL, Sept. 30, 1997. Tribal codes requiring sex offender registration; Skokomish Tribal Code, Title IX, 9.02B.005 9.02B.095; Hoopa Valley Tribe, Title 47; Eastern Band of Cherokee Indians, Chapter 14, Art. 10; Nez Perce Tribal Code, §4-1-140 through 4-1-150.

80. See, e.g., Tohono O'odham Nation of Arizona, INDIAN COUNTRY TODAY(May 24, 2000) available at $\mathrm{http}: / / \mathrm{www}$.indiancountry.com/?1630.

81. Psychologist Bonnie Burstow eloquently explains the importance of historical context in addressing trauma: "... [Traumatized] people or communities tend to become frozen in time, periodically reexperiencing the past or responding to the present as if it were the past. Different types of dissociation and disconnection occur, with individuals and communities dissociating from aspects of the past that are associated with the trauma; with people and communities fleeing events, history, or memory; with people dissociated from all or parts of their traumatized bodies; with thought separating from feeling; with people disconnecting from others; and with the ties that bind a community coming asunder." See also Bonnie Burstow, Toward a Radical Understanding of Trauma and Trauma Work, 9 VIOLENCE AGAINST WOMEN 1293, 1303 (2003).

82. Jane Caputi, Take Back What Doesn't Belong to Me": Sexual Violence, Resistance and the “Transmission of Affect, 26 WOMEN's STUDIES INTERNATIONAL FORUM 1, 11 (2003).

83. Peggy Reeves Sanday, Rape and the Silencing of the Feminine, in RAPE: AN HISTORICAL AND SOCIAL ENQUIRY (Sylvana Tomaselli \& Roy Porter eds., 1986) at 85.

84. Maria Braveheart-Jordan \& Lemyra Debruyn, So She May Walk in the Balance: Integrating the Impact of Historical Trauma in the Treatment of Native American Indian Women, in RACISM IN THE LIVES OF WOMEN (Jeanne Adleman \& Gloria M. Enguidanos, eds., 1995).

85. See, e.g., Helen Jaskoski, "My Heart Will Go Out": Healing Songs of Native American Women, 4 INTERNATIONAL JOURNAL OF WOMEN'S STUDIES 118 (1981).

86. See generally, e.g. JAMES AXTELL, THE WHITE INDIANS OF COLONIAL AMERICA (Ye Galleon Press 1979).

87. LAUREL THATCHER ULRICH, GOOD WIVES: IMAGE AND REALITY IN THE LIVES OF WOMEN IN NORTHERN NEW ENGLAND, 1650-1750 97 (Alfred A. Knopf 1982) (1980).

88. Who's THE SAVAGE? 17 (David R. Wrone \& Russell S. Nelson eds., Robert E. Kreiger Publishing Co. 1982) (1973).

89. SHARON BLOCK, RAPE AND SEXUAL POWER IN EARLY AMERICA (University of North Carolina Press, forthcoming 2005) (for more information, see http://www.humanities.uci.edu/history/faculty/block/).

90. JAMES AXTELL, THE EUROPEAN AND THE INDIAN 182 (1981).

91. Jo-Anne Fiske, Colonization and the Decline of Women's Status: The Tsimshian Case, 17 FEMINIST STUDIES 509, 510-15 (1991).

92. Diron D'Artaguiette, Journal of Diron D'Artaguiette, 1722-1723, in TRAVELS IN THE AMERICAN 
COLONIES: 1690-1744, at 73 (Newton D. Merenes ed., The Macmillan Co., 1916).

93. Mark St. Pierre \& Tilda Long Soldier, Walking in the Sacred Manner 81 (Simon \& Schuster 1995).

94. Even the controversial word "squ*w" is laden with sexual overtones. The evolution of this slur has been linked to the stereotype of Native women as inappropriately lustful and sexually promiscuous. See, e.g., C. Richard King, De/Scribing Squ*w: Indigenous Women and Imperial Idioms in the United States, 27 AM. INDIAN CULTURE \& RES. J. 1, 3-4 (2003).

95. VIRGINIA MARIE BOUVIER, WOMEN AND THE CONQUEST OF CALIFORNIA, 1542-1840: CODES OF SLENCE 12 (The University of Arizona Press 2001).

96. Carol Devens, Separate Confrontations: Gender as a Factor in Indian Adaptation to European Colonization in New France, 38 AM. Q. 461, 467-468 (1986).

97. Tarrell Awe Agahe Portman \& Roger D. Herring, Debunking the Pocahontas Paradox: The Need for a Humanistic Perspective, 40 J. HuMANISTIC CounsEling EdUC. \& DEVElopMENT 185, 185 89 (2001).

98. See generally KAREN ANDERSON, CHAIN HER BY ONE FOOT: THE SUBJUGATION OF WOMEN IN SEVENTEENTH-CENTUR Y NEW FRANCE (Routledge 1991); CAROL DEVENS, COUNTERING COLONIZATION: NATIVE AMERICAN WOMEN AND GREAT LAKES MISSIONS, 1630-1900 (University of California Press 1992); and see Lisa J. Udel, Revision and Resistance: The Politics of Native Women's Motherwork, 22 FrONTIERS 43, 45-46 (2001).

99. See generally Anderson, supra note 32.

100. See, e.g., Card, supra note 24.

101. See, e.g. Karen Vieira Powers, Conquering Discourses of "Sexual Conquest": Of Women, Language, and Mestizaje, 11 COLONIAL LATIN AM. REV. 7 (2002).

102. See generally Sarah Deer, Expanding the Network of Safety, 4 TRIBAL L. J. (forthcoming 2004) at http://tlj.unm.edu.

103. J. McLerran, Trappers' Brides \& Country Wives: Native American Women in the Paintings of Alfred Jacob Miller, 18 AM. INDIAN CULTURE \& RES. J. 1, 5 (1994).

104. See, e.g., Francis Jennings, Virgin Land and Savage People, 23 AM. Q. 519 (1971); see also King, supra note 94 , at 6.

105. BOUVIER, supra note 95 , at 13 .

106. M.M. Slaughter, American Indian Tribes: "Not as Belonging to but as Existing Within, 11 L. \& CRITIQUE 25, 34 (2000).

107. Eirlys M. Barker, Princesses, Wives and Wenches: White Perceptions of Southeastern Indian Women to 1770, WOMEN \& FREEDOM IN EARLY AM., Jan. 31, 1997, at 44.

108. Philosopher Tim Rohrer has written extensively about the use of the word "rape" as a political metaphor in contemporary international politics. He explores the metaphorical logic of "Nation as person" -- thereby linking the conception of armed invasion to the conception of rape. Tim Rohrer, The Metaphorical Logic of (Political) Rape Revisited: The New Wor(l)d Order 10 METAPHOR \& SYMBOLIC ACTIVITY (1995).

109. Matthew F. Bokovoy, Humanist Sentiment, Modern Spanish Heritage, and California Mission Commemoration, 1769-1915, 48 J. OF SAN DIEGO HIST. 175, 175 available at http://www.sandiegohistory.org/journal/2002-3/humanit.htm; see also, DEE BROWN, BURY MY HEART AT WOUNDED KNEE 38-39 (Henry Holt \& Co. 1991) (1970).

110. See generally BOUVIER, supra note 95 . See also Antonia I. Castañeda, Sexual Violence in the Politics and Policies of Conquest: Amerindian Women and the Spanish Conquest of Alta California, in BUILDING WITH OUR HANDS: NEW DIRECTIONS IN CHICANA STUDIES 15 (Adela de 
la Torre \& Beatriz M. Pesquera eds., University of California Press 1993).

111. BOUVIER, supra note 95 , at 46-47.

112. See John Demos, The TRIED AND the TRUe: Native AmeriCAN Women CONFronting COlOnIZATION 89 (Oxford University Press 1995); CAROLYN Ross JoHNSTON, CHEROKEE WOMEN IN CRISIS: TRAIL OF TEARS, CIVIL WAR, AND ALLOTMENT, 1838-1907 57 (University of Alabama 2003).

113. David Roberts, The Long Walk to Bosque Redondo, 28 SMTTHSONIAN 46 (1997).

114. Albert L. Hurtado, When Strangers Met: Sex and Gender on Three Frontiers, 17 FronTIERS 52, 63-68 (1996).

115. Sharon Block, Rape and Race in Colonial Newspapers, 1728-1776, 27 JOURNALISM HiST. 146, 146-55 (2002) (discussing a Pennsylvania Gazatte article from 1776 which reported that two Indian women, one of whom was pregnant, had been murdered during a rape attempt by two white men).

116. See, e.g., ANGIE DEBO, A HISTORY OF THE INDIANS OF THE UNITED STATES 159 (University of Oklahoma Press: Norman 1976), quoting General George Crook: "It was of no unfrequent occurrence for an Indian to be shot down in cold blood, or a squaw to be raped by some brute. Such a thing as a white man being punished for outraging an Indian was unheard of. ..."

117. Bokovoy, supra note 109.

118. Leslie E. Korn, Community Trauma and Development, 4 FOURTH WORLD J. 1, 1 (2002).

119. James A. Sandos, Between Crucifix and Lance: Indian-White Relations in California, 1769-1848, in CONTESTED EDEN: CALIFORNIA BEFORE THE GOLD RUSH 196, 206 (Ramón A. Guitérrez \& Richard J. Orsi eds., University of California Press 1998).

120. Rose Stremlau, Rape Narratives on the Northern Paiute Frontier: Sarah Winnemucca, Sexual Sovereignty, and Economic Autonomy, 1844-1891, in PORTRAITS OF WOMEN IN THE AMERICAN WEST (Dee Garceau ed., forthcoming 2005).

121. Id.

122. Castañeda, supra note 110 at 29.

123. Braveheart-Jordan \& DeBruyn, supra note 84 , at 349.

124. For example, one legal scholar has acknowledged that contemporary genocidal rape forces women to be "vessels through which the dilution, disappearance, and destruction of their own ethnic group occur[s]." Sherrie L. Russell-Brown, Rape as an Act of Genocide, 21 BERKELEY J. INT'L L. 350, 355 (2003).

125. See Clara Sue Kidwell, What Would Pocahontas Think Now? Women and Cultural Persistence, 17 Callaloo 149, 149-150 (1994).

126. Hurtado, supra 114 , at 59.

127. DEMOS, supra note 112 , at 71.

128. SaRAH WinNemuCCa Hopkins, LIFE AMONG the PiUTES 48 (University of Nevada Press 1994) (1883).

129. See e.g., Jane Lawrence, The Indian Health Service and the Sterilization of Native American Women, 24 AM. INDIAN Q. 400 (2000); Sally J. Torpy, Native American Women and Coerced Sterilization: On the Trail of Tears in the 1970s, 24 AM. INDIAN CULTURE \& RES. J. 1 (2000); Bruce E. Johansen, Reprise/Forced Sterilizations: Native Americans and the "Last Gasp of Eugenics", 15 NATIVE AM. 44 (1998); Carol Chiago Lujan, Women Warriors: American Indian Women, Crime and Alcohol, 7 WOMEN \& CRIM. JUST. 9 (1995).

130. See generally Andrea Smith, Soul Wound: The Legacy of Native American Schools, (2003) at 
http://www.amnestyusa.org/amnestynow/soulwound.html.

131. Id.; see also Charles Horejsi, Reactions by Native American Parents to Child Protection Agencies: Cultural and Community Factors, 71 CHILD WELFARE 330 (1992).

132. See Robert A. Trennert, Victorian Morality and the Supervision of Indian Women Working in Phoenix, 1906-1930, 21 J. SoCIAL HIST. 113 (1988).

133. Steve Russell, Indigenous Peoples: The Jurisprudence of Colonialism, in AMERICAN INDIAN THOUGHT 218, (Anne Waters ed., 2004).

134. Feminist theory, like indigenous theory, does not connote a single, unified theory -- but rather a grouping of similar philosophies.

135. See, e.g., Carol Devens, Separate Confrontations: Gender as a Factor in Indian Adaptation to European Colonization in New France, 38 AM. QUARTERLY 461 (1986).

136. Nadera Shalhoub-Kevorkian, Towards a Cultural Definition of Rape: Dilemmas in Dealing with Rape Victims in Palestinian Society, 22 WOMEN's STUDIES INTERNATIONAL FORUM 157, 171 (1999).

137. Laura Hengehold, Remapping the Event: Institutional Discourses and the Trauma of Rape, 26 SIGNS, 189, 192 (2000) (emphasis added).

138. Matthew L.M. Fletcher notes, "[t]ribal advocates must never forget how it is Indians and Indian tribes came to be in the position they are in now." Fletcher, supra note 70.

139. For example, there may be strong evidence that indigenous legal responses to sexual violence in pre-colonial times included castration and/or the death penalty. See AXTELL, supra note 86. Such legal remedies may be inappropriate or unacceptable in a contemporary context.

140. Robert Allen Warrior, TRIBAL SECRETS: RECOVERING AMERICAN INDIAN INTELLECTUAL TRADITIONS xx (University of Minnesota Press, 1995).

141. See generally id.

142. Philosopher Ann J. Cahill describes this as "the ethical wrongs of rape." See ANN J. CAHILL, RETHINKING RAPE 167 (Cornell University Press 2001). Legal theory should be distinguished from a behavioral "causal" theory, which seeks to explain why rape happens.

143. See, e.g., Ann T. Spence, A Contract Reading of Rape Law: Redefining Force to Include Coercion, 37 COLUM. J. L. \& SoC. PROBS. 57 (2003).

144. See, e.g., Aya Gruber, Pink Elephants 4 WM. \& MARY J. WOMEN \& L. 203 (1997).

145. Keith Burgess-Jackson, Rape and Persuasive Definition, 25 CANADIAN J. OF PHIL. 415, 443 (1995). Eric Reitan describes this approach to rape as "territorially defined." Eric Reitan, Rape as an Essentially Contested Concept, 16 HYPATIA 43, 51 (2001).

146. Id. at 444.

147. Id. at 446.

148. Id. at 448.

149. See, e.g., Carine M. Mardorossian, Toward a New Feminist Theory of Rape, 27 SIGNS 743, 747 (2002).

150. Hengehold, supra, note 137 at 211.

151. See, e.g., Gloria Valencia-Weber \& Christine P. Zuni, Domestic Violence and Tribal Protection of Indigenous Women in the United States, 69 ST. JOHN'S L. REV. 69 (1995).

152. Ann J. Cahill, Foucault, Rape, and the Construction of the Feminine Body, 15 HYPATIA 43, 45 (2000).

153. See, e.g. Janice Gould, American Indian Women's Poetry: Strategies of Rage and Hope, 20 SIGNS 797 (1995). 
154. Roberta Makashay Hendrickson, Victims and Survivors: Native American Women Writers, Violence Against Women, and Child Abuse, 8 STUD. IN AM. INDIAN LTTERATURES 13, 14 (1996).

155. See, e.g., Rosalva Aida Hernandez Castillo, Reinventing Tradition:, The Women's Law, 19 CULTURAL SURVIVAL QUARTERLY 24 (195).

156. See, e.g., HOPKINS supra note 128.

157. Condition of the Indian Tribes: Hearing Before the Special Comm. Appointed under Joint Resolution of March 3, 1865, 39th Cong. 2d sess., 370-371 (1867) (statement of Strike-the-Ree), reprinted in WHO'S THE SAVAGE 113-1 15 (David S. Wrone \& Russell S. Nelson, Jr., eds., 1982).

158. Daniel L. Lowery, Developing a Tribal Common Law Jurisprudence, 18 AM. INDIAN L. REV. 379, 400 (1993)( discussing Kuwanjyomia v. Kuwanhyomia, No. TC-CV-344-84, slip op. at 2-4 (Tuba City Dist. Ct. April 9, 1990).

159. See generally Russel Lawrence Barsh, Putting the Tribe in Tribal Court: Possible? Desirable? 8 KAN. J.L. \& PUB. POL'Y 74 (1998).

160. See, e.g., Pat Sekaquaptewa, Evolving the Hopi Common Law, 9 KAN. J. L. \& PUB. PoL'Y 761 $(2000)$.

161. William Bartram, a biologist who traveled through Creek and Cherokee country in 1773, wrote "A [Creek] Indian never attempts, nay, he cannot use towards a woman amongst them any indelicacy, either in action or language. I never saw or heard of an instance of an Indian beating his wife or other female, or reproving them in anger or harsh language." William Bartram, Observations on the Creek and Cherokee Indians, 1789, 3 TRANSACTIONS OF THE AM. ETHNOLOGICAL SOC'Y. 55 (1853), reprinted in A CREEK SOURCEBOOK (William C. Sturtevant, ed., Garland Publishing 1987).

162. LAW 35TH, in LAWS OF THE CREEK NATION 24 (Antonio J. Waring. ed., Univ. of Ga. Press 1960) (1824) (handwritten by Chief Chilly McIntosh, whose first language was not English).

163. Ohland Morton, The Government of the Creek Indians, 8 CHRON. OF OKLA. 42, 54 (1930).

164. See generally Carrie E. Garrow \& Sarah Deer, Tribal Criminal Law and Procedure (AltaMira Press 2004).

165. Maria-Barbara Watson-Franke, A World in Which Women Move Freely Without Fear of Men: An Anthropological Perspective on Rape, 24 WOMEN's STUDIES INTERNATIONAL 599, 601(2002) (quoting Claire R. Farrer).

166. See Joseph BruchaC, OUR Stories Remember 37 (Fulcrum Publishing 2003); EKKEHART MALOTKI, THE BEDBUGS' Night DANCE AND OTHER HOPI TALES OF SEXUAL ENCOUNTER viii (1997). See also Josey Vogels, Sexual Healing, See Magazine, Nov. 13, 2003 (discussing the teachings of Dr. TerryTafoya, a psychologist who studies the use of storytelling as a tool of education in Native cultures) available athttp://www.seemagazine.com/Issues/2003/1113/josey.htm.

167. I also wish to acknowledge that relying on written records and/or English translations are not always recommended. In many tribal cultures, the most sacred laws are passed down through oral traditions in the tribal language, and it would be inappropriate to condense them to words.

168. See Raymond D. Fogelson, Who Were the Ani-Kutani? An Excursion into Cherokee Historical Thought, 31 ETHNOHISTORY 255, 255-263 (1984) (discussing the origin and history of the AniKutani tribe).

169. Harlan I. Smith, Some Ojibwa Myths and Traditions, 19 J. OF AMERICAN FOLKLORE 215, 227 (1906).

170. Mona M. Smith, The Strength of Native Women, 5 NewS From INDIAN COUNTRY 15 (1991).

171. Id. 


\section{Deer}

172. Johnny Frank, Taa' $i i$ ' Ti' in NEERIHIINJIK: We TraVELED FROM PlaCE To PlaCE 279 (Craig Mishler, ed. 1995).

173. This juxtaposition is described in depth by Ross Harrison, Rape: A Case Study in Political Philosophy, in RAPE: AN HISTORICAL AND SOCIAL INQUIRY 41 (Eds. Sylvana Tomaselli \& Roy Porter eds., 1986).

174. See Lisa M. Poupart, The Familiar Face of Genocide: Internatlized Oppression among American Indians, 18 HYPATIA 86 (2003) (drawing a line between the historical and contemporary oppression of Native people and the high rate of intra tribal violence which plagues some tribal communities).

175. Marcie R. Rendon, Facing Spiritual and Sexual Abuse in the Native Community, 18 THE CIRCLE, 9 (July 1997).

176. Sherry L. Hamby, Sexual Victimization in Indian Country: Barriers and Resources for Native Women Seeking Help, NAT'L ElECTRONIC NETWORK ON VIOLENCE AGAINST WOMEN 4 (May 2004).

177. Linda TuHiwani SMITH, DECOLONIZING METHOdOlOGES: RESEARCH AND INDIGENOUS PEOPLES 16 (Zed Books Ltd. 1999). 